\title{
Evaluation of the Genetic Relationship between Longevity and Growth, Milk Yield and Fertility Traits in the Sahiwal Breed in Kenya
}

\author{
Benjamin Musyimi Musingi, ${ }^{1,2}$ Leah Mumbi Mahianyu'3 ${ }^{3}$ Dorcas Mutheu Musingi ${ }^{4}$ \\ ${ }^{1}$ Animal Breeding and Genomics Group, Department of Animal Sciences Egerton University, Egerton, Kenya \\ ${ }^{2}$ Department of Biological Sciences Egerton University, Egerton, Kenya \\ ${ }^{3}$ National Police Service, Department of Kenya Police, Njoro, Kenya \\ ${ }^{4}$ Department of Building and Civil Engineering Water Section, Technical University of Mombasa, Mombasa, Kenya \\ Email: Musyimi.b@gmail.com
}

How to cite this paper: Musingi, B.M., Mahianyu, L.M. and Musingi, D.M. (2022) Evaluation of the Genetic Relationship between Longevity and Growth, Milk Yield and Fertility Traits in the Sahiwal Breed in Kenya. Open Journal of Animal Sciences, 12, 16-35.

https://doi.org/10.4236/ojas.2022.121002

Received: September 7, 2021

Accepted: November 7, 2021

Published: November 10, 2021

Copyright $\odot 2022$ by author(s) and Scientific Research Publishing Inc. This work is licensed under the Creative Commons Attribution International License (CC BY 4.0).

http://creativecommons.org/licenses/by/4.0/

\begin{abstract}
Direct selection for longevity results in improved health and fitness and even milk production of cows. However, longevity is lowly heritable and phenotypic information is obtained at the end of an animal's life. Traits expressed early in life and which are favorably correlated to longevity can be useful in selecting for this trait. The aim of this study was to estimate genetic correlations between longevity and age at first calving, first lactation calving interval, number of services per conception, first lactation milk yield, and first parity lactation length. Heritability estimates for measures of longevity were also calculated. The measures of longevity were time between birth and last milking in days (Long1), time between first calving and last milking record in months (Long2), number of lactations initiated (Long3), and total number of days in lactation over all lactations (Long4), total milk yield over all lactations $(\mathrm{kg})$ (Long5). A series of five-variate animal models were fitted to estimate the nature and magnitude of genetic and phenotypic correlations between each measure of longevity and the fertility and production traits. Genetic correlations between measures of longevity and age at first calving, calving interval and number of services per conception were negative ranging from $-0.14 \pm 0.05$ to $-0.96 \pm 0.06,-0.06 \pm 0.03$ to $-0.67 \pm 0.08$ and $-0.02 \pm 0.02$ to $-0.73 \pm 0.34$, respectively. Correlations between measures of longevity and first lactation milk yield ranged from $0.88 \pm 0.01$ to $0.97 \pm 0.03$. Those with first parity lactation length ranged from -0.10 to 0.72 . Long1, Long 4 and Long5, which measure time between birth and last milking day, total number of days in lactation over all lactations and total milk yield over all lactations (kg), respectively, had the highest heritability estimates. These three could
\end{abstract}


therefore be used to directly select for longevity. Among the traits studied, first lactation milk yield and age at first calving had the highest genetic correlation with measures of longevity. Therefore, first lactation milk yield and age at first calving could, therefore, be used to indirectly select for longevity.

\section{Keywords}

Correlated Response, Fertility, Genetic Correlation, Longevity, Sahiwal

\section{Introduction}

Longevity or the age at which a cow leaves the breeding herd is a trait of great economic importance in dairy and beef cattle breeding [1]. Productive longevity can also be described as the amount of calving's per female [2]. In beef and dairy cattle, longevity plays a considerable role in the farm economy by increasing the profit realized per cow and enables greater response to selection because fewer animals exit the herd due to involuntary culling [3], a situation that provides greater selection intensity among females, and surplus heifers for sale [1].

Although milk production is considered the single most important trait in dairy farming, cattle breeding programs are changing their breeding objectives to include longevity and other traits (type and functional) [1] [4]. This enables cows to meet the challenges of high milk production. Direct selection for longevity results in improved health and fitness [3] and even milk production of cows [5]; therefore, breeding for longevity is considered to have ethical and economic benefits since it results in a favorable response in the profitability of beef and dairy cattle enterprises [3]. However, inclusion of longevity in the breeding objective is hampered because the trait is lowly heritable [5] [6] and the delay in availability of phenotypic information [7], which may lead to increase in generation interval [5].

Availability of traits expressed early in life and which are favorably correlated to longevity can be useful in selecting for this trait. Genetic correlations between longevity and linear and fertility traits have been reported to be low to moderately positive [5] [8] [9]. Reproductive performance is a crucial component of culling criteria and therefore influences longevity in cattle herds and is regarded as the single most economically important trait in beef cattle. Since productive longevity is closely related to fertility, it is important to consider the genetic effects of both traits simultaneously. Despite its importance in cattle, longevity has not been studied in the Sahiwal cattle although it has been recommended for inclusion in the breed's breeding objective [10] [11] [12]. Estimates of genetic correlations between longevity and other performance traits, which can be used as selection criteria for longevity for the breed are also lacking.

\section{Materials and Methods}

Pedigree and performance data Sahiwal cattle in Kenya were obtained from the 
Sahiwal National Stud at Kenya Agricultural and Livestock Research Organization (KALRO), Naivasha. A database was created by systematically entering each animal, sire and dam, date of birth and sex into a database in MSAccess. The data were checked for consistency to ensure that all animals were ordered sequentially based on the date of birth such that no progeny was born before any of its parents. Also checked was presence of cyclic pedigrees (i.e. no animal appeared as both male or female) and no animal appeared as both sire and dam. The foregoing was achieved using the Animal Breeder's ToolKit (ABTK [8]). Measures of longevity related to productive life were: time between birth and last milking record in days (Long1), time between first calving and last milking record in days (Long2), number of lactations initiated (Long3), and total number of days in lactation over all lactations (Long4), total milk yield over all lactations (kg) (Long5). Performance data for each cow included fertility traits (Age at first calving (AFC), Calving interval (CI), first parity number of services per conception (NS)) and production traits (first lactation milk yield (FLMY) and first parity lactation length (LL)).

\section{Data Analysis}

\subsection{Estimation of the Correlation between Longevity and Performance Traits}

A series of five-variate animal models were fitted to estimate nature and magnitude of genetic and phenotypic correlations between each measure of longevity and the fertility and production traits. The measures of longevity were time between birth and last milking day (Long1), the time between first calving and last milking record in months (Long2), the number of lactations initiated (Long3), and the total number of days in lactation over all lactations (Long4), total milk yield over all lactations (kg) (Long5). Fertility traits were AFC, CI, NS, while production traits included FLMY and FLL. In this model, the traits were assumed to be different but correlated traits. The covariance structure of the model analyzing five traits was:

$$
G=\operatorname{variance}\left[\begin{array}{c}
a_{1} \mathrm{FLL} \\
a_{2} \mathrm{FLMY} \\
a_{3} \mathrm{AFC} \\
a_{4} \mathrm{CI} \\
a_{5} \mathrm{NS}
\end{array}\right]=\left[\begin{array}{lllll}
g_{11} & g_{12} & g_{13} & g_{14} & g_{15} \\
& g_{22} & g_{23} & g_{24} & g_{25} \\
& & g_{33} & g_{34} & g_{35} \\
& & & g_{44} & g_{45} \\
s y m m & & & & g_{55}
\end{array}\right] \otimes A=G_{0} \otimes A
$$

where $G_{0}$ is the genetic (co)variance matrix between animal effects; $\otimes=$ Kronecker product and $A=$ numerator relationship matrix among animals. The residual variance among record of different traits was assumed to zero; $g_{i i}$ is the variance for trait $i$ and $g_{i j}$ is the covariance between any two traits, $i$ and $j$.

\subsection{Genetic Correlation}

Genetic correlation between two traits $i$ and $j, r_{g_{i, j}}$ was estimated as: 


$$
r_{g_{i, j}}=\frac{\sigma_{i, j}}{\left(\sigma_{i i}^{2} \cdot \sigma_{j j}^{2}\right)^{0.5}}
$$

where $\sigma_{i, j}, \sigma_{i i}^{2}$ and $\sigma_{j j}^{2}$ are the covariance between traits $i$ and $j$, variance of trait $i$ and $j$, respectively.

\section{Results and Discussion}

Means and standard deviations for selection criteria for measures of longevity are given in Table 1. Heritability estimates for measures of longevity from multivariate analysis were generally higher than those from univariate analysis. This could be due to the additional information from correlated traits in multivariate analysis [12]. The mean values for measures of longevity from birth and first calving were similar to those reported by [5] for Brazilian Holsteins and Nilforooshan and Edriss who reported values ranging from 57.2 months and 30.1 months for Long1 and Long2 respectively. For Brazillian Holsteins, [13] reported values of 60 and 33 months, respectively.

Long5 or milk production in all lactations is an indicator of a cow's delay to involuntary culling. With increased milk production culling is based preferentially on production leading to higher proportion of cows in a herd with higher productive capacity and longer herd life. Average for Long3 of 1.5 was lower than values of 2.7 and 2.8 reported for Brazilian and US Holsteins, respectively [13] [14]. Higher values of 3.0 and 2.4 for Slovak Holsteins and Simmental dairy cows, respectively, have been reported [15] [16]. In the Kenyan Sahiwal herd, cows remained on average 2231.1 days, 1172.7 days from birth (Long1) or first calving (Long2), respectively, an average of 738 days in milk till they exited the herd through death or culling. With an increase in total days in milk, cows are expected to produce more milk, accompanied by a lower occurrence of reproductive, udder and conformation problems [17]. Mean values of Long1 (74.4 months) and Long2 (39.1 months) were higher than those reported for Brazilian Holsteins (60 and 33 months, respectively) and 57.2 months and 30.1 months, respectively reported by [18]. The higher values reported in the current study could be due to breed differences, where exotic dairy breeds in temperate and

Table 1. Means, standard deviations, minimum and maximum for longevity measures related to productive life for Sahiwal cattle in Kenya.

\begin{tabular}{ccccc}
\hline Measure & Mean & Standard deviation & Minimum & Maximum \\
\hline Long1, days & 2231.1 & 887.8 & 960.0 & 6246.0 \\
Long2, days & 1172.7 & 703.7 & 226.0 & 4720.0 \\
Long3, count & 2.7 & 1.4 & 1.0 & 11.0 \\
Long4, days & 738.0 & 428.4 & 10.0 & 3147.0 \\
Long5, kg & 3425.5 & 3534.2 & 10.0 & $11,616.0$ \\
\hline
\end{tabular}

Longevity was defined as time between birth and last milking day (Long1), time between first calving and last milking record in months (Long2), number of lactations initiated (Long3), and total number of days in lactation over all lactations (Long4), total milk yield over all lactations (kg) (Long5). 
tropical climatic conditions have been shown to exit herds earlier due to involuntary culling [19] compared to the zebu.

Estimates of components of additive genetic and residual variances for measures of longevity related to productive life are shown in Table 1. Additive genetic variances ranged from 0.06 (Long3) to 366,033 (Long5). Corresponding heritability estimates were low, with the highest being $0.097 \pm 0.04$ (Long5). All measures of longevity had high estimates of residual variances and low estimates of additive genetic variance hence the low estimates of heritability. The heritability estimates found in the current study of 0.08 to 0.10 were within the range reported for different cattle populations under tropical conditions of 0.06 to 0.18 [19] [20] [21]. Heritability estimates cattle populations in temperate climatic conditions ranged from 0.02 to 0.10 [14] [22]. The low heritability estimates for measures of longevity from linear models yield lower estimates compared to survival models partly due to inclusion of censored records and time-dependent variables [23] [24] since the environmental conditions affecting cow survival changes over time.

Co-variance components, heritability estimates and genetic correlations between selection criteria and measures of longevity are given in. The heritability estimates for measures of longevity were low, ranging from 0.03 to 0.13 (Table 2). This indicates that longevity is influenced more by environmental factors, meaning that direct selection for these traits would yield low genetic gains. Other studies which reported low heritability estimates include [25] who reported estimates ranging from 0.05 to 0.07 . For traits expressed early in life relative to the measures of longevity in the current study, first lactation milk yield had the highest heritability estimate, ranging from 0.12 to 0.23 followed by first parity lactation length (0.07 to 0.12 ) (Table 3 ).

Lower heritability estimates were obtained for first parity calving interval (0.01 to 0.05$)$ and number of services per conception (0.01 to 0.04$)$. Among the fertility traits, age at first calving had higher heritability estimates, ranging from 0.04 to 0.10 .

Genetic correlations between fertility traits and measures of longevity were negative ranging from -0.02 to -0.95 . This indicates that cows with long first

Table 2. Estimates of additive genetic variance $\left(\sigma_{a}^{2}\right)$, residual $\left(\sigma_{e}^{2}\right)$ and heritability estimates $\left(h^{2}\right)$ for measures of longevity from multivariate analyses for the Sahiwal cattle in Kenya.

\begin{tabular}{cccccc}
\hline Parameter & Long1 & Long2 & Long3 & Long4 & Long5 \\
\hline$\sigma_{a}^{2}$ & $24,121.1$ & $28,761.1$ & 0.11 & 5595.0 & $398,380.2$ \\
$\sigma_{e}^{2}$ & $312,591.0$ & $319,900.1$ & 1.50 & $127,280.1$ & $3,811,821.3$ \\
$h^{2}$ & $0.07 \pm 0.08$ & $0.08 \pm 0.01$ & $0.07 \pm 0.02$ & $0.04 \pm 0.02$ & $0.09 \pm 0.01$ \\
\hline
\end{tabular}

Longevity was defined as time between birth and last milking day (Long1), time between first calving and last milking record in months (Long2), number of lactations initiated (Long3), and total number of days in lactation over all lactations (Long4), total milk yield over all lactations (kg) (Long5). 
Table 3. Co-variance components, heritability and genetic correlations between measures of longevity and performance traits for Sahiwal cattle in Kenya.

\begin{tabular}{|c|c|c|c|c|c|c|}
\hline Longevity & Performance trait & $\sigma_{a}^{2}$ & $\sigma_{e}^{2}$ & $h^{2} \pm \mathrm{se}$ & $\sigma_{1,2}$ & $r_{g}$ \\
\hline \multirow{6}{*}{ Long1 } & & $24,121.1$ & $312,591.0$ & $0.07 \pm 0.08$ & & \\
\hline & Age at first calving, mo & 1.8 & 21.4 & $0.08 \pm 0.01$ & -58 & $-0.28 \pm 0.06$ \\
\hline & First parity calving interval, days & 209.9 & $15,002.0$ & $0.01 \pm 0.01$ & -3498.7 & $-0.67 \pm 0.08$ \\
\hline & First parity lactation length, days & $10,147.0$ & $91,570.1$ & $0.10 \pm 0.06$ & -1634.1 & $-0.10 \pm 0.06$ \\
\hline & First parity milk yield & $43,565.9$ & $190,761.0$ & $0.19 \pm 0.02$ & $31,490.0$ & $0.97 \pm 0.03$ \\
\hline & First parity services/conception, No & 0.07 & 2.7 & $0.02 \pm 0.03$ & -0.63 & $-0.02 \pm 0.02$ \\
\hline \multirow[t]{6}{*}{ Long2 } & & $28,761.1$ & $319,900.1$ & $0.08 \pm 0.01$ & & \\
\hline & Age at first calving, mo & 1.97 & 22.70 & $0.08 \pm 0.02$ & -54.2 & $-0.14 \pm 0.05$ \\
\hline & First parity calving interval, days & 739.8 & $14,821.1$ & $0.05 \pm 0.04$ & -1853.4 & $-0.24 \pm 0.04$ \\
\hline & First parity lactation length, days & 2463.2 & $18,347.1$ & $0.12 \pm 0.03$ & 6065.1 & $0.72 \pm 0.03$ \\
\hline & First parity milk yield & $49,277.0$ & $210,931.1$ & $0.19 \pm 0.02$ & $36,473.0$ & $0.97 \pm 0.04$ \\
\hline & First parity services/conception, No & 0.093 & 2.49 & $0.04 \pm 0.03$ & -41.9 & $-0.18 \pm 0.14$ \\
\hline \multirow[t]{6}{*}{ Long3 } & & 0.11 & 1.50 & $0.07 \pm 0.02$ & & \\
\hline & Age at first calving, mo & 1.29 & 11.6 & $0.10 \pm 0.02$ & -0.36 & $-0.96 \pm 0.06$ \\
\hline & First parity calving interval, days & 215.6 & $15,672.0$ & $0.01 \pm 0.02$ & -0.78 & $-0.16 \pm 0.08$ \\
\hline & First parity lactation length, days & 9170.63 & $91,824.2$ & $0.10 \pm 0.03$ & 2.56 & $0.08 \pm 0.19$ \\
\hline & First parity milk yield & $49,121.1$ & $166,000.1$ & $0.23 \pm 0.04$ & 68.6 & $0.93 \pm 0.06$ \\
\hline & First parity services/conception, No & 0.03 & 2.43 & $0.01 \pm 0.01$ & -0.04 & $-0.70 \pm 0.18$ \\
\hline \multirow[t]{6}{*}{ Long4 } & & 5595.0 & $127,280.1$ & $0.04 \pm 0.02$ & & \\
\hline & Age at first calving, mo & 1.2 & 27.3 & $0.04 \pm 0.02$ & -69.5 & $-0.85 \pm 0.08$ \\
\hline & First parity calving interval, days & 323.4 & $15,033.1$ & $0.02 \pm 0.03$ & -168.8 & $-0.13 \pm 0.07$ \\
\hline & First parity lactation length, days & $10,543.0$ & $82,951.1$ & $0.11 \pm 0.02$ & 1761.0 & $0.23 \pm 0.04$ \\
\hline & First parity milk yield & $33,851.0$ & $217,541.0$ & $0.13 \pm 0.01$ & $12,063.1$ & $0.88 \pm 0.01$ \\
\hline & First parity services/conception, No & 0.03 & 2.4 & $0.01 \pm 0.09$ & -9.4 & $-0.73 \pm 0.34$ \\
\hline \multirow[t]{6}{*}{ Long5 } & & $398,380.2$ & $3,811,821.3$ & $0.09 \pm 0.01$ & & \\
\hline & Age at first calving, mo & 1.4 & 12.0 & $0.10 \pm 0.01$ & -121.2 & $-0.16 \pm 0.03$ \\
\hline & First parity calving interval, days & 341.2 & 12,037 & $0.03 \pm 0.02$ & -699.3 & $-0.06 \pm 0.03$ \\
\hline & First parity lactation length, days & 165.2 & 2054.2 & $0.07 \pm 0.02$ & 2731.0 & $0.37 \pm 0.02$ \\
\hline & First parity milk yield & 6110.2 & $208,386.0$ & $0.18 \pm 0.01$ & $129,339.1$ & $0.95 \pm 0.05$ \\
\hline & First parity services/conception, No & 0.04 & 2.4 & $0.02 \pm 0.01$ & -70.5 & $-0.55 \pm 0.06$ \\
\hline
\end{tabular}

Longevity was defined as time between birth and last milking day (Long1), time between first calving and last milking record in months (Long2), number of lactations initiated (Long3), and total number of days in lactation over all lactations (Long4), total milk yield over all lactations (kg) (Long5).

lactation CI, and which calved first later or required more services per conception were less likely to remain in the productive herd. Studies which have reported similar negative correlations include [26]. In this study, cows that required more services per conception or had longer calving intervals were at 
greater risk of being culled. Similar results were reported for French Holsteins by [27]. [28] reported that cows with higher age at first calving tended to have a shorter length of productive life and were associated with a higher risk of being culled [29]. Thus, selecting for earlier age at first calving will lead to an increase in longevity, apart from shortening generation interval [30] and decreasing replacement expenses [31]. In general, late first calving in cows is associated with fertility and health problems, which may be exhibited in the entire life of a cow [18] [28] [32]. Genetic correlations between measures of longevity and first lactation milk yield and lactation length were positive and moderate to high, and ranged from 0.41 to 0.99 . However, heritability estimates of fertility traits were close to 0 , as found in the current study and in literature [33] [34].

Long1, Long3, Long4 and Long5, which measure time between birth and last milking day, number of lactations initiated, total number of days in lactation over all lactations and total milk yield over all lactations $(\mathrm{kg})$, respectively, had the highest heritability estimates. These two could therefore be used to directly select for longevity. The genetic correlations between Long1 and Long5 and FLMY and AFC were high and positive and negative, respectively. Therefore, selecting for more FLMY and shorter AFC would lead to correlated increase longevity. As such FLMY and AFC could therefore be used to indirectly select for longevity.

Measures of longevity related to productive life were: time between birth and last milking record in months (Long1), time between first calving and last milking record in months (Long2), number of lactations initiated (Long3), and total number of days in lactation over all lactations (Long4), total milk yield over all lactations (kg) (Long5).

Estimates of components of additive genetic and residual variances for measures of longevity related to productive life are shown in Table 4. Additive genetic variances were lower than residual variances for all measures of longevity related to productive life (Table 4). This implies that some factors causing differences between animals were not captured during the data recording process and were therefore not included in the model of analysis. The values of additive

Table 4. Means, standard deviations, minimum and maximum for longevity measures related to productive life for Sahiwal cattle in Kenya.

\begin{tabular}{ccccc}
\hline Measure & Mean & Standard deviation & Minimum & Maximum \\
\hline Long1, days & 2231.1 & 887.8 & 960.0 & 6246.0 \\
Long2, days & 1172.7 & 703.7 & 226.0 & 4720.0 \\
Long3, count & 2.7 & 1.44 & 1.0 & 11.0 \\
Long4, days & 738.0 & 428.4 & 10.0 & 3147.0 \\
Long5, $\mathrm{kg}$ & 3425.5 & 3534.2 & 10.0 & $11,616.0$ \\
\hline
\end{tabular}

Longevity was defined as (Long1), time between first calving and last milking record in months (Long2), number of lactations initiated (Long3), and total number of days in lactation over all lactations (Long4), total milk yield over all lactations $(\mathrm{kg})$ (Long5). 
genetic variance ranged from 0.058 (Long3) to 366,033 (Long5). Heritability estimates for measures of longevity related to productive life were low, with the highest being $0.097 \pm 0.04$ (Long5).

For measures of survival from birth, there was a decrease of $31.5 \%$ and $42.8 \%$ in the survival rate between birth to 36 months (Long6_36) to 72 months (Long6_72) and from calving to 44 months and 96 months, respectively. Survival rates up to 12, 24 and 54 months from first calving was similar to measures of survival from birth. The reduction in survival for both measures of survival to different ages indicates reduced ability of cows to persist in the herd due to voluntary or involuntary culling. Measures of estimated mean, median and mode of variance components and heritability were all similar, indicating that the posterior distributions of these parameters were more or less symmetric (Table 5). Heritability estimates for measures of survival from birth ranged from 0.084 (Long6_44) to 0.104 (Long6_128), and were lower than those estimated from first calving (Table 5).

Additive genetic variances for survival measures from first calving increased from twelve months after first calving (Long7_12) to 96 months after first calving (Long7_96). Heritability estimates ranged from 0.090 (Long7_12) to 0.119 (long7_96). Heritability estimates for longevity measured as survival from birth or first calving to last day in milk (Table 4 and Table 6) were generally low compared to those related to productive life (Table 7).

Direct selection for longevity results in improved health and fitness [3] and even milk production of cows [5] (Table 8); therefore, breeding for longevity is considered to have ethical and economic benefits since it results in favorable response in profitability of beef and dairy cattle enterprises [3]. Many breeding programs across the world have therefore begun to recognize the economic importance of longevity and have estimated genetic parameters for longevity and included the trait in breeding objective [1] [4] [35] [36]. Inclusion of longevity in the breeding objective is hampered because the trait is lowly heritable [5] [6] and the delay in availability of phenotypic information [7]. Traits expressed early in life and which are favorably correlated with longevity can be used as selection criteria [9]. However, genetic correlations between longevity and fertility, growth and milk yield traits have not been estimated for the Kenyan Sahiwal population [11].

Table 5. Estimates of additive genetic variance $\left(\sigma_{a}^{2}\right)$, residual $\left(\sigma_{e}^{2}\right)$ and heritability estimates $\left(h^{2}\right)$ for measures of productive life for the Sahiwal cattle in Kenya.

\begin{tabular}{cccccc}
\hline Parameter & Long1 & Long2 & Long3 & Long4 & Long5 \\
\hline$\sigma_{a}^{2}$ & $25,208.9$ & $24,740.5$ & 0.06 & 8820.0 & 366,033 \\
$\sigma_{e}^{2}$ & $296,090.1$ & $318,344.1$ & 1.51 & $118,783.2$ & $3,397,910$ \\
$h^{2}$ & $0.078 \pm 0.038$ & $0.072 \pm 0.027$ & $0.038 \pm 0.032$ & $0.069 \pm 0.034$ & $0.097 \pm 0.037$ \\
\hline
\end{tabular}

Longevity was defined as (Long1), time between first calving and last milking record in months (Long2), number of lactations initiated (Long3), and total number of days in lactation over all lactations (Long4), total milk yield over all lactations (kg) (Long5). 
Table 6. Data structure use for analysis of measures of longevity for the Sahiwal cattle in Kenya.

\begin{tabular}{ccc}
\hline Measure of longevity & $\begin{array}{c}\text { No. of animals } \\
\text { with records }\end{array}$ & $\begin{array}{c}\text { Number } \\
\text { of sires }\end{array}$ \\
\hline Time between birth and last milking record in months & 2524 & 303 \\
Time between first calving and last milking record in months & 1991 & 302 \\
Number of lactations initiated & 2707 & 317 \\
Total number of days in lactation over all lactations & 2707 & 317 \\
Total milk yield over all lactations (kg) & 1990 & 303 \\
Survival from birth to 44 months & 1887 & 209 \\
Survival from birth to 56 months & 1806 & 201 \\
Survival from birth to 80 months & 1623 & 178 \\
Survival from birth to 92 months & 1433 & 163 \\
Survival from birth to 104 months & 1292 & 145 \\
Survival from birth to 128 months & 1012 & 138 \\
Survival from first calving to 12 months & 1507 & 169 \\
Survival from first calving to 36 months & 1411 & 153 \\
Survival from first calving to 60 months & 1121 & 122 \\
Survival from first calving to 84 & 915 & 106 \\
Survival from first calving to 96 months & 862 & 96 \\
\hline
\end{tabular}

Table 7. Posterior descriptive estimates for additive genetic variance $\left(\sigma_{a}^{2}\right)$, residual $\left(\sigma_{e}^{2}\right)$ and heritability estimates for measures of survival from birth for the Sahiwal cattle in Kenya.

\begin{tabular}{|c|c|c|c|c|c|c|}
\hline Parameter & Mean $\pm S D$ & Mode & Median & Min & $\operatorname{Max}$ & IC-95\% \\
\hline \multicolumn{7}{|l|}{ Long6_44 } \\
\hline$\sigma_{a}^{2}$ & $0.092 \pm 0.071$ & 0.113 & 0.082 & 0.010 & 0.162 & 0.010 to 0.153 \\
\hline$\sigma_{e}^{2}$ & $1.007 \pm 0.032$ & 0.955 & 1.008 & 0.902 & 1.116 & 0.902 to 1.039 \\
\hline$h^{2}$ & $0.084 \pm 0.053$ & 0.105 & 0.075 & 0.011 & 0.126 & 0.011 to 0.128 \\
\hline \multicolumn{7}{|l|}{ Long6_56 } \\
\hline$\sigma_{a}^{2}$ & $0.094 \pm 0.076$ & 0.081 & 0.072 & 0.009 & 0.182 & 0.054 to 0.170 \\
\hline$\sigma_{e}^{2}$ & $1.017 \pm 0.036$ & 0.979 & 1.006 & 0.905 & 1.110 & 0.892 to 1.053 \\
\hline$h^{2}$ & $0.085 \pm 0.058$ & 0.076 & 0.067 & 0.010 & 0.141 & 0.057 to 0.139 \\
\hline \multicolumn{7}{|l|}{ Long6_80 } \\
\hline$\sigma_{a}^{2}$ & $0.112 \pm 0.061$ & 0.092 & 0.093 & 0.010 & 0.183 & 0.010 to 0.182 \\
\hline$\sigma_{e}^{2}$ & $1.014 \pm 0.043$ & 1.009 & 1.004 & 0.900 & 1.111 & 0.904 to 1.104 \\
\hline$h^{2}$ & $0.100 \pm 0.041$ & 0.084 & 0.085 & 0.011 & 0.142 & 0.012 to 0.142 \\
\hline \multicolumn{7}{|l|}{ Long6_92 } \\
\hline$\sigma_{a}^{2}$ & $0.114 \pm 0.063$ & 0.111 & 0.110 & 0.038 & 0.162 & 0.013 to 0.182 \\
\hline$\sigma_{e}^{2}$ & $1.004 \pm 0.049$ & 1.005 & 1.003 & 0.897 & 1.111 & 0.913 to 1.125 \\
\hline$h^{2}$ & $0.102 \pm 0.042$ & 0.099 & 0.099 & 0.040 & 0.127 & 0.014 to 0.139 \\
\hline
\end{tabular}




\section{Continued}

$\begin{array}{ccccccc}\text { Long6_104 } & & & & & & \\ \sigma_{a}^{2} & 0.127 \pm 0.075 & 0.192 & 0.117 & 0.010 & 0.219 & 0.010 \text { to } 0.269 \\ \sigma_{e}^{2} & 1.105 \pm 0.054 & 1.009 & 1.004 & 0.904 & 1.104 & 0.901 \text { to } 1.511 \\ h^{2} & 0.103 \pm 0.056 & 0.160 & 0.105 & 0.011 & 0.165 & 0.012 \text { to } 0.151 \\ \text { Long6_128 } & & & & & & \\ \sigma_{a}^{2} & 0.116 \pm 0.081 & 0.121 & 0.106 & 0.001 & 0.193 & 0.013 \text { to } 0.176 \\ \sigma_{e}^{2} & 1.007 \pm 0.064 & 0.996 & 1.001 & 0.907 & 1.107 & 0.920 \text { to } 1.117 \\ h^{2} & 0.104 \pm 0.057 & 0.108 & 0.094 & 0.001 & 0.148 & 0.014 \text { to } 0.136\end{array}$

Key: Longevity was defined as survival from birth to 44 months (Long6_44), 56 months (Long6_56), 80 months (Long6_80), 92 months (Long6_92), 104 months (Long6_104), and 128 months (Long6_128); sd = standard deviation, IC-95\% = 95\% confidence interval for an estimate; Min and Max are the minimum and maximum values.

Table 8. Posterior descriptive estimates for additive genetic variance ( $\left.\sigma_{a}^{2}\right)$, residual $\left(\sigma_{e}^{2}\right)$ and heritability estimates $\left(h^{2}\right)$ for measures of survival from first calving for the Sahiwal cattle in Kenya.

\begin{tabular}{|c|c|c|c|c|c|c|}
\hline Parameter & Mean SD & Mode & Median & Min & $\operatorname{Max}$ & IC-95\% \\
\hline \multicolumn{7}{|l|}{ Long7_12 } \\
\hline$\sigma_{a}^{2}$ & $0.099 \pm 0.006$ & 0.071 & 0.076 & 0.007 & 0.110 & 0.016 to 0.098 \\
\hline$\sigma_{e}^{2}$ & $0.997 \pm 0.057$ & 1.002 & 0.997 & 0.912 & 1.102 & 0.898 to 1.097 \\
\hline$h^{2}$ & $0.090 \pm 0.044$ & 0.066 & 0.070 & 0.008 & 0.085 & 0.018 to 0.082 \\
\hline \multicolumn{7}{|l|}{ Long7_36 } \\
\hline$\sigma_{a}^{2}$ & $0.108 \pm 0.007$ & 0.061 & 0.069 & 0.007 & 0.097 & 0.018 to 0.103 \\
\hline$\sigma_{e}^{2}$ & $0.999 \pm 0.051$ & 0.977 & 0.990 & 0.906 & 1.098 & 0.898 to 1.099 \\
\hline$h^{2}$ & $0.097 \pm 0.053$ & 0.059 & 0.065 & 0.008 & 0.081 & 0.020 to 0.085 \\
\hline \multicolumn{7}{|l|}{ Long7_60 } \\
\hline$\sigma_{a}^{2}$ & $0.115 \pm 0.071$ & 0.061 & 0.091 & 0.008 & 0.109 & 0.028 to 0.110 \\
\hline$\sigma_{e}^{2}$ & $1.005 \pm 0.054$ & 1.012 & 1.009 & 0.895 & 1.097 & 0.900 to 1.110 \\
\hline$h^{2}$ & $0.103 \pm 0.043$ & 0.057 & 0.083 & 0.008 & 0.090 & 0.030 to 0.090 \\
\hline \multicolumn{7}{|l|}{ Long7_84 } \\
\hline$\sigma_{a}^{2}$ & $0.117 \pm 0.007$ & 0.071 & 0.081 & 0.007 & 0.110 & 0.024 to 0.163 \\
\hline$\sigma_{e}^{2}$ & $1.005 \pm 0.052$ & 1.000 & 1.003 & 0.905 & 1.095 & 0.904 to 1.106 \\
\hline$h^{2}$ & $0.104 \pm 0.046$ & 0.066 & 0.075 & 0.008 & 0.092 & 0.026 to 0.128 \\
\hline \multicolumn{7}{|l|}{ Long7_96 } \\
\hline$\sigma_{a}^{2}$ & $0.140 \pm 0.007$ & 0.095 & 0.096 & 0.015 & 0.156 & 0.022 to 0.169 \\
\hline$\sigma_{e}^{2}$ & $1.008 \pm 0.056$ & 0.994 & 1.004 & 0.908 & 1.113 & 0.901 to 1.115 \\
\hline$h^{2}$ & $0.119 \pm 0.035$ & 0.087 & 0.088 & 0.016 & 0.123 & 0.023 to 0.132 \\
\hline
\end{tabular}

Key: Longevity was defined as survival from first calving as survival from for 12 months (Long7_12), 36 (Long7_36), 60 (Long7_60), 84 (long7_84) and 96 months (Long7_96) from first calving; sd = standard deviation, IC- $95 \%=95 \%$ confidence interval for an estimate; Min and Max are the minimum and maximum values. 
Genetic improvement of the Sahiwal in Kenya breed is carried out under a closed nucleus breeding program (CNBP). Closed nucleus breeding programs are associated with high inbreeding levels and low effective population sizes due to increased focus on a few high performing often closely related animals [37]. Longevity, milk yield and reproductive performance and milk yield have been shown to decrease while, rate of disposal or loss of replacement heifers before first calving, age at puberty increased due to inbreeding through reduced growth [38]. For every increase of $1 \%$ in inbreeding, productive life has been reported to decrease by about 13 days [39]. Cows with high inbreeding level have also been reported to have a higher risk of being culled [40], reduced reproductive efficiency and stay ability. The objectives of this study were 1) To estimate genetic and phenotypic parameters for longevity; 2) To estimate genetic relationship between longevity and milk yield and fertility traits; 3) To determine the effect of inbreeding on traits of economic importance in the Kenyan Sahiwal population.

\section{Study Methodology}

Measures of longevity related to productive life i.e. were defined alternatively as time between birth and last milking record in days (Long1), length of productive life or functional longevity (days) (Long2), number of lactations initiated (Long3), total number of days in lactation over all lactations (Long4) and total milk yield over all lactations, kg (Long5) [21]. Variance components, genetic and phenotypic parameters for longevity were estimated using a linear model using the expectation maximization method in WOMBAT [41] using a convergence criterion of $10^{-9}$. Measures of longevity related to survival (survival from birth to 44 months (Long6_44), 56 months (Long6_56), 80 months (Long6_80), 92 months (Long6_92), 104 months (Long6_104), and 128 months (Long6_128) and survival from first calving as survival from for 12 months (Long7_12), 36 (Long7_36), 60 (Long7_60), 84 (long7_84) and 96 months (Long7_96) from first calving) were analyzed as threshold traits assumed to have an underlying continuous distribution.

The threshold model relates survival to a given age in a categorical scale with a normal underlying continuous scale. Variance components for survival measures were estimated via Bayesian inference using THRGIBBS1F90 [42]. Outputs from this software were used to obtain a posteriori estimate using POSTGIBBSF90 [42]. Convergence of all Bayesian analyses was verified using the R program using [43] and Heidelberger and Welch diagnostics, from the Bayesian Output Analysis Program-BOA [44].

The second objective estimated genetic correlations between longevity and fertility and milk yield and lactation length in the first lactation. Genetic correlations between each measure of longevity (Long1, Long2, Long3, Long4 and Long5) and age at first calving, first parity services per conception, calving interval, milk yield and lactation were estimated through a series five-variate analyses via a linear model. 
The third objective dealt with assessing the effect of inbreeding on traits of economic importance. Effects of inbreeding on the traits were determined by fitting four regression models (linear, quadratic, exponential and Michaelis-Menten) to the errors generated by the animal model. The inbreeding coefficient ( $\mathrm{Fi}$ ) for each individual in the pedigree was calculated as the probability that two alleles are identical by descent according to the method of [45]. Estimates of variance and estimated breeding values were obtained by performing univariate analyses on first lactation milk yield (LMY), lactation length (LL), Age at first calving (AFC) and calving interval (CI) using the following a univariate animal model using WOMBAT software [41]. Analysis of pedigree, inbreeding coefficient (F) and equivalent complete generations was estimated using ENDOG version 4.5 computer program [46]. The linear, quadratic and Michaelis-Menten models were fitted to the vector of errors for each trait generated from the univariate analysis.

The first step in inclusion of a trait in the breeding objective of a given breeding program entails estimation of genetic and phenotypic parameters, its correlation with other traits of economic importance and to quantify the effect of inbreeding on the trait(s) especially for closed nucleus breeding programs. This study was carried out to provide genetic and phenotypic parameters for longevity, its correlation with other traits in the breeding objective of the Kenyan Sahiwal cattle and to estimate inbreeding depression for traits of economic importance

\section{Genetic Parameters}

Genetic parameters for measures of longevity related to productive life or survival were estimated using linear and threshold models, respectively. Estimates of heritability for longevity measures estimated using threshold models (survival measures) were higher than those estimated using linear models (measures related to productive life). Long7_96 had the highest additive genetic variance and heritability estimate, and therefore should be used for genetic evaluation of longevity in Sahiwal cattle in Kenya.

Longevity is quite important in dairy and beef cattle herds from an economic, herd-health and animal welfare point of view. Intensive selection for production and reproduction traits without considering functional and type traits leads to decreased longevity [47] [48]. In the current study, the estimates of additive genetic variances and heritability were significantly different from 0 based on their $95 \%$ confidence intervals. Similar results were reported by [49]. The $95 \%$ confidence intervals were also wide. Heritability estimates for measures of longevity are dependent on breed [25] and method of analysis [49] and definition of longevity [5] [6] [21]. In general heritability estimates of longevity are low regardless of method of evaluation, breed or species [5] [6] [21] [49]. However, given the immense economic importance of this trait, it is worthwhile to consider it as a selection criterion in cattle breeding. The benefits of increased longevity are 
numerous. Longer productive life means lower replacement and treatment costs associated with reproductive and animal health disorders, feet, udder and other functional traits [23] [35] [50]. Because of this countries are changing the breeding objectives for dairy and beef cattle to include longevity. For instance, by 2014, 12 countries included longevity in national genetic evaluations either as a single trait analyzed through survival analysis or in a multiple trait model [36]. Further, Evaluation of sires for functional longevity in breeding programs is very vital because it would complement estimated breeding values for production traits [51].

The measures of longevity used in the current study relate to function longevity which is defined as the ability to delay involuntary culling due to factors other than production (lameness, fertility problems, mastitis, or other diseases). For instance, survival to predefined ages as used in the current study captures information on culling early in life which has the most detrimental effect on herd profitability. Milk production is deemed the single most important factor affecting productive life due to its direct effect on herd profitability. Cows in low milk production classes have a higher relative risk of being culled [52].

Although it was not considered in the current study, voluntary selection for milk components influences cow risk of being culled. Cows with low protein and fat percentage have higher risk of being culled [53]. These results are similar to those reported by [54] and [55] for Holstein cows in Canada and France, respectively.

\section{Genetic Correlations between Longevity and Fertility and Production Traits}

Direct selection for longevity is a trait of great economic importance in beef and dairy cattle enterprises [1] [4] [35]. But its inclusion in the breeding objective is hampered because the trait is lowly heritable [5] [6] and the delay in availability of phenotypic information [7] [56]. Other challenges that hinder the selection for longevity include the proper measure of productive live compatible with short generation intervals and the choice of the right analysis that is capable of capturing environmental factors influencing the trait [5] [6] [21] [25]. The challenge of selecting young bulls for longevity is compounded by the fact that majority of their daughters are still alive at the end of first lactation [57]. The presence of large amounts of censored records leads to low accuracy of estimated breeding values for productive life [58]. Accuracy of genetic evaluations for longevity can be increased by including information on other traits during analysis, preferably those expressed early in life [57] [59]. Such traits include type traits, which have been used to classify and identify desirable traits associations with longevity [25].

Traits such as body size composite and udder traits have been reported to have a significant influence on productive life in Lithuanian dairy cattle [60]. [25] investigated the phenotypic correlation between longevity and type traits. 
However, this study did not find any significant association between type traits and risk of culling in Brazilian Holsteins. Contrary to this finding, other studies have reported udder traits especially udder depth and fore udder attachment to have a large impact on longevity [54] [61] [62]. Final score and angularity (dairy character) have also been found to significantly influence longevity in Czech Holsteins [63]. Traits expressed early in life and which are favorably correlated with longevity can be used as selection criteria [9]. The current study systematically assessed the genetic associations between traits expressed early in life and longevity in the Sahiwal cattle in Kenya. Chapter 4 of this study found that first lactation milk yield had the highest genetic correlation. Therefore this trait should be used as a selection criterion for longevity.

\section{Inbreeding Depression for Traits of Economic Importance}

Effects of inbreeding on the traits were determined by fitting four regression models (linear, quadratic, exponential and Michaelis-Menten) to the errors generated by the animal model. The linear, exponential and Michaelis-Menten models were significant $(\mathrm{P}<0.05)$ for all the studied traits while the quadratic model was only significant $(P<0.05)$ for calving interval. Inbreeding had a positive effect on calving interval, age at first calving, and lactation length, shortening calving both interval and age at first calving and increasing lactation length. The relation between inbreeding and depression of traits was not linear, with greater depression after 15\% inbreeding. Genetic evaluation of the Kenyan Sahiwal should account for inbreeding. However, the results of the current study and those of [64] indicate that as inbreeding level increases, inbreeding depression increases at an increasing rate. This could imply that at higher levels of inbreeding (>15\%) apart from additive effects of inbreeding, there could be inter-locus interaction between loci with identical alleles by descent, leading increased depression.

The implications of these results have a profound effect on how inbreeding is accounted for in genetic evaluations. Most genetic evaluations either ignore inbreeding or fit a linear regression to account for inbreeding [65] [66] [67]. The results of the current study indicate the need to consider effect of inbreeding on traits of economic importance, but not as linear regression. The very high significance of the Michaelis-Menten model, which theoretically implies an increasing rate of depression as inbreeding level increases indicates that inbreeding should be accounted for using non-linear regression models. The mating plan for any breeding program should be designed so as to control future rates of inbreeding while achieving genetic gain.

Closed nucleus breeding programs, such as that for the Sahiwal cattle in Kenya are able to achieve faster rates of genetic gain but are associated with high inbreeding levels and low effective population sizes due to increased focus on a few high performing often closely related animals [66]. Although studies of inbreeding depression on longevity are rare, it has been shown that longevity, milk 
yield and reproductive performance decrease while, rate of disposal or loss of replacement heifers before first calving, age at puberty increase due to inbreeding through reduced growth [38]. For every increase of $1 \%$ in inbreeding, productive life has been reported to decrease by about 13 days [39]. Cows with high inbreeding levels have also been reported to have a higher risk of being culled [40], reduced reproductive efficiency and stay ability.

\section{Conclusion}

Among measures of longevity survival from first calving to 96 months had the highest heritability estimate, and therefore should be used for genetic evaluation of longevity in Sahiwal cattle in Kenya. Inbreeding led to significant depression in fertility and production traits studied. The relationship between inbreeding and depression of traits was not linear, with greater depression after $15 \%$ inbreeding. First lactation milk yield had the highest genetic correlation with longevity, and should therefore be used as a selection criterion for longevity.

\section{Conflicts of Interest}

The authors declare no conflicts of interest regarding the publication of this paper.

\section{References}

[1] Banga, C.B., Neser, F.W.C. and Garrick, D.J. (2013) Derivation of Economic Values of Longevity for Inclusion in the Breeding Objectives for South African Dairy Cattle. International Proceedings of Chemical Biological and Environmental Engineering, 60, 69-73.

[2] Varona, L., Moreno, C. and Altarriba, J. (2012) Genetic Correlation of Longevity with Growth, Post-Mortem, Docility and Some Morphological Traits in the Pirenaica Beef Cattle Breed. Animal, 6, 873-879. https://doi.org/10.1017/S1751731111002072

[3] Garcia, J., Anderson, D.P., Herring, A.D. and Riley, D.G. (2015) Economic Analysis of Selecting for Cow Longevity. Selected paper prepared for presentation at the Southern Agricultural Economics Association's 2015 Annual Meeting, Atlanta, Georgia, 31 January-3 February 2015, Article ID: 196863.

[4] Banga, C.B., Neser, F.W.C. and Garrick, D.J. (2014) Breeding Objectives for Holstein Cattle in South Africa. South African Journal of Animal Science, 44, 199-214. https://doi.org/10.4314/sajas.v44i3.1

[5] Kern, E.L., Cobuci, J.A., Costa, C.N. and Pimentel, C.M.M. (2014) Factor Analysis of Linear Type Traits and Their Relation with Longevity in Brazilian Holstein Cattle. Asian Australasian Journal of Animal Science, 27, 784-790.

https://doi.org/10.5713/ajas.2013.13817

[6] Van Pelt, M.L., Meuwissen, T.H.E., de Jong, G. and Veerkamp, R.F. (2015) Genetic Analysis of Longevity in Dutch Dairy Cattle Using Random Regression. Journal of Dairy Science, 98, 4117-4130. https://doi.org/10.3168/jds.2014-9090

[7] Lagrotta, M.R., Euclydes, R.F., Verneque, R.S., Santana-Júnior, M.L., Pereira, R.J. and Torres, R.A. (2010) [Relationship between Morphological Traits and Milk Yield in Gir Breed Cows]. Pesquisa Agropecuária Brasileira, 45, 423-429. (In Portuguese) 
https://doi.org/10.1590/S0100-204X2010000400011

[8] Zavadilová, L., Nemcová, E., Štípková, M. and Bouška, J. (2009) Relationships between Longevity and Conformation Traits in Czech Fleckvieh Cows. Czech Journal of Animal Science, 54, 387-394. https://doi.org/10.17221/1685-CJAS

[9] Van Melis, M.H., Oliveira, H.N., Eler, J.P., Ferraz, J.B.S., Casellas, J. and Varona, L. (2010) Additive Genetic Relationship of Longevity with Fertility and Production Traits in Nellore Cattle Based on Bivariate Models. Genetics and Molecular Research, 9, 176-187. https://doi.org/10.4238/vol9-1gmr710

[10] Roessler, R., Ilatsia, E.D. and Valle Zárate, A. (2010) Optimized Breeding Strategies for the Local Sahiwal Cattle in Kenya: Use Values and Important Breeding Traits. Fifth All African Conference on Animal Agriculture, Addis Ababa, Ethiopia, 25-28 October 2010, 218-221.

[11] Ilatsia, E.D., Migose, S.A., Muhuyi, W.B. and Kahi, A.K. (2011) Sahiwal Cattle in Semi Arid Kenya: Genetic Aspects of Growth and Survival Traits and Their Relationship to Milk Production and Fertility. Tropical Animal Health and Production, 43, 1572-1582. https://doi.org/10.1007/s11250-011-9845-X

[12] Ilatsia, E.D., Roessler, R., Kahi, A.K., Piepho, H.-P. and Zárate, V. (2012) Production Objectives and Breeding Goals of Sahiwal Cattle Keepers in Kenya and Implications for a Breeding Programme. Tropical Animal Health and Production, 44, 519-530. https://doi.org/10.1007/s11250-011-9928-8

[13] Kern, E.L., Cobuci, J.A., Costa, C.N., McManus, C.M. and Neto, J.B. (2015) Genetic Association between Longevity and Linear Type Traits of Holstein Cows. Scientia Agricola, 72, 203-209. https://doi.org/10.1590/0103-9016-2014-0007

[14] Tsuruta, S., Misztal, I. and Lawlor, T.J. (2005) Changing Definition of Productive Life in US Holstein: Effect on Genetic Correlations. Journal of Dairy Science, 88, 1156-1165. https://doi.org/10.3168/jds.S0022-0302(05)72782-X

[15] Potocnik, K., Gantner, V., Krsnik, J., Štepec, M., Logar, B. and Gorjanc, G. (2011) Analysis of Longevity in Slovenian Holstein Cattle. Acta Agriculturae Slovenica, 98, 93-100. https://doi.org/10.2478/v10014-011-0025-5

[16] Strapák, P., Juhás, P. and Strapáková, E. (2011) The Relationship between the Length of Productive Life and the Body Conformation Traits in Cows. Journal of Central European Agriculture, 12, 239-254.

https://doi.org/10.5513/JCEA01/12.2.905

[17] Cruickshank, J., Weigel, K.A., Dentine, M.R. and Kirkpatrick B.W. (2002) Indirect Prediction of Herd Life in Guernsey Dairy Cattle. Journal of Dairy Science, 85, 1307-1313. https://doi.org/10.3168/jds.S0022-0302(02)74195-7

[18] Nilforooshan, M.A. and Edriss, M.A. (2004) Effect of Age at First Calving on Some Productive and Longevity Traits in Iranian Holsteins of the Isfahan Province. Journal of Dairy Science, 87, 2130-2135. https://doi.org/10.3168/jds.S0022-0302(04)70032-6

[19] Sewalem, A., Kistemaker, G.J. and Miglior, F. (2010) Relationship between Female Fertility and Production Traits in Canadian Holsteins. Journal of Dairy Science, 93, 4427-4434. https://doi.org/10.3168/jds.2009-2915

[20] M'hamdi, N., Aloulou, R., Bouallegue, M., Brar, S.K. and Hamouda, M.B. (2014) Study on Functional Longevity of Tunisian Holstein Dairy Cattle Using a Weibull Proportional Hazard Model. Livestock Science, 132, 173-176. https://doi.org/10.1016/j.livsci.2010.05.011

[21] Kern, E.L., Cobuci, J.A., Costa, C.N., Neto, J.B., Campos, T.P., Campos, R.V. and 
McManus, C.M. (2014) Genetic Parameters for Longevity Measures in Brazilian Holstein Cattle Using Linear and Threshold Models. Archives Animal Breeding, 57, 1-12. https://doi.org/10.7482/0003-9438-57-033

[22] Vollema, A.R. and Groen, A.F. (1996) Genetic Parameters of Longevity Traits of an Upgrading Population of Dairy Cattle. Journal of Dairy Science, 79, 2261-2267. https://doi.org/10.3168/jds.S0022-0302(96)76603-1

[23] Ducrocq, V., Quaas, R.L., Pollak, E.J. and Casella, G. (1988) Length of Productive Life of Dairy Cows. 2. Variance Component Estimation and Sire Evaluation. Journal of Dairy Science, 71, 3070-3079. https://doi.org/10.3168/jds.S0022-0302(88)79907-5

[24] Forabosco, F., Bozzi, R., Filippini, F., Boettcher, P., Van Arendonk, J.A.M. and Bijma, P. (2006) Linear Model vs. Survival Analysis for Genetic Evaluation of Sires for Longevity in Chianina Beef Cattle. Livestock Science, 101, 191-198.

https://doi.org/10.1016/j.livprodsci.2005.11.010

[25] Kern, E.L., Cobuci, J.A., Costa, C.N. and Ducrocq, V. (2017) Phenotypic Relationships between Type Traits and Productive Life Using a Piecewise Weibull Proportional Hazard Model. Scientia Agricola, 75, 470-478.

https://doi.org/10.1590/1678-992x-2017-0153

[26] Sewalem, A., Miglior, F., Kistemaker, G.J., Sullivan, P. and Van Doormaal, B.J. (2008) Relationship between Reproduction Traits and Functional Longevity in Canadian Dairy Cattle. Journal of Dairy Science, 91, 1660-1668.

https://doi.org/10.3168/jds.2007-0178

[27] Beaudeau, F., Ducrocq, V., Fourchon, C. and Seegers, H. (1994) Effect of Disease on Productive Life of French Holstein Dairy Cows Assessed by Survival Analysis. Journal of Dairy Science, 78, 103-117. https://doi.org/10.3168/jds.S0022-0302(95)76621-8

[28] Zavadilová, L. and Štípková, M. (2013) Effect of Age at First Calving on Longevity and Fertility Traits for Holstein Cattle. Czech Journal of Animal Science, 58, 47-57. https://doi.org/10.17221/6614-CJAS

[29] Sewalem, A., Kistemaker, G.J. and Van Doormaal, B.J. (2005b) Relationship between Type Traits and Longevity in Canadian Jerseys and Ayrshires Using a Weibull Proportional Hazards Model. Journal of Dairy Science, 88, 1552-1560. https://doi.org/10.3168/jds.S0022-0302(05)72824-1

[30] Pirlo, G., Miglior, F. and Speroni, M. (2000) Effect of Age at First Calving on Production Traits and on Difference between Milk Yield Returns and Rearing Costs in Italian Holsteins. Journal of Dairy Science, 83, 603-608. https://doi.org/10.3168/jds.S0022-0302(00)74919-8

[31] Gardner, R.W., Smith, L.W. and Park, R.L. (1988) Feeding and Management of Dairy Heifers for Optimal Lifetime Productivity. Journal of Dairy Science, 71, 996-999. https://doi.org/10.3168/jds.S0022-0302(88)79646-0

[32] Páchová, E., Zavadilová, L. and Sölkner, J. (2005) Genetic Evaluation of the Length of Productive Life in Holstein Cattle in the Czech Republic. Czech Journal of Animal Science, 50, 493-498. https://doi.org/10.17221/4253-CJAS

[33] Zink, V., Lassen, J. and Štípková, M. (2012) Genetic Parameters for Female Fertility and Milk Production Traits in First Parity Czech Holstein Cows. Czech Journal of Animal Science, 57, 108-114. https://doi.org/10.17221/5562-CJAS

[34] Albarrán-Portillo, B. and Pollott, G.E. (2013) The Relationship between Fertility and Lactation Characteristics in Holstein Cows on United Kingdom Commercial Dairy Farms. Journal of Dairy Science, 96, 635-646.

https://doi.org/10.3168/jds.2012-5632 
[35] Forabosco, F., Jakobsen, J.H. and Fikse, W.F. (2009) International Genetic Evaluation for Direct Longevity in Dairy Bulls. Journal of Dairy Science, 92, 2338-2347. https://doi.org/10.3168/jds.2008-1214

[36] Interbull (2014) Description of National Genetic Evaluation Systems for Dairy Cattle Traits as Applied in Different Interbull Member Countries.

https://interbull.org/ib/geforms

[37] Mészáros, G., Pálos, J., Ducrocq, V. and Sölkner, J. (2010) Heritability of Longevity in Large White and Landrace Sows Using Continuous Time and Grouped Data Models. Genetics Selection Evolution, 42, Article No. 13.

http://www.gsejournal.org/content/42/1/13

https://doi.org/10.1186/1297-9686-42-13

[38] Du Toit, J., van Wyk, J.B. and Maiwashe, A. (2012) Assessment of Inbreeding Depression for Functional Herd Life in the South African Jersey Breed Based on Level and Rate of Inbreeding. South African Journal of Animal Science, 42, 55-62. https://doi.org/10.4314/sajas.v42i1.7

[39] Canadian Dairy Network (CDN) (2008) Subject: Quantifying Inbreeding Depression. http://www.cdn.ca

[40] Rokouei, M., VaezTorshizi, R., MoradiShahrbabak, M., Sargolzaei, M. and Sørensen, C. (2010) Monitoring Inbreeding Trends and Inbreeding Depression for Economically Important Traits of Holstein Cattle in Iran. Journal of Dairy Science, 93, 3294-3302. https://doi.org/10.3168/jds.2009-2748

[41] Meyer, K. (2007) WOMBAT-A Tool for Mixed Model Analyses in Quantitative Genetics by Restricted Maximum Likelihood (REML). Journal of Zheijang University Science B, 8, 815-821. https://doi.org/10.1631/jzus.2007.B0815

[42] Misztal, I., Tsuruta, S., Strabel, T., Auvray, B., Druet, T. and Lee, D.H. (2002) BLUPF90 and Related Programs (BGF90). Proceedings of the 7 th World Congress on Genetics Applied to Livestock Production, Montpellier, France, 19-23 August 2002, Communication 28-07.

[43] Geweke, J. (1992) Evaluating the Accuracy of Sampling-Based Approaches to the Calculation of Posterior Moments. In: Bernardo, J.M., Berger, J.O., Dawid, A.P. and Smit, A.F.M., Eds., Bayesian Statistics 4, Oxford University Press, Oxford, 169-193.

[44] Smith, B.J. (2005) Bayesian Output Analysis Program (BOA) Version 1.1 User's Manual. Iowa State University, Iowa City, IA.

https://www.researchgate.net/publication/228388233_Bayesian_Output_Analysis_P $\underline{\text { rogram_BOA_Version_11_User's_Manual }}$

[45] VanRaden, P.M. (1992) Accounting for Inbreeding and Crossbreeding in Genetic Evaluation of Large Populations. Journal of Dairy Science, 75, 3136-3144. https://doi.org/10.3168/jds.S0022-0302(92)78077-1

[46] Gutiérrez, J.P. and Goyache, F. (2005) A Note on ENDOG: A Computer Program for Analysing Pedigree Information. Journal of Animal Breeding and Genetics, 122, 172-176. https://doi.org/10.1111/j.1439-0388.2005.00512.x

[47] Engblom, L., Lundeheim, N., Strandberg, E., del, P.S., Dalin, A.M. and Andersson, K. (2008) Factors Affecting Length of Productive Life in Swedish Commercial Sows. Journal of Animal Science, 86, 432-441. https://doi.org/10.2527/jas.2007-0310

[48] Knaus, W. (2009) Dairy Cows Trapped between Performance Demands and Adaptability. Journal of Science Food and Agriculture, 89, 1107-1114. https://doi.org/10.1002/jsfa.3575

[49] Yazdi, M.H., Visscher, P.M., Ducroq, V. and Thompson, R. (2002) Heritability, Reliability of Genetic Evaluations and Response to Selection in Proportional Hazards 
Models. Journal of Dairy Science, 85, 1563-1577. https://doi.org/10.3168/jds.S0022-0302(02)74226-4

[50] Essl, A. (1998) Longevity in Dairy Cattle Breeding: A Review. Livestock Production Science, 57, 79-89. https://doi.org/10.1016/S0301-6226(98)00160-2

[51] Ducrocq, V. and Sölkner, J. (1998) The Survival Kit-V3.0, a Package for Large Analyses of Survival Data. 6th World Congress on Genetics Applied To Livestock Production, Armidale, 11-16 January 1998, 447-448.

[52] Ducrocq, V. (1994) Survival Analysis, a Statistical Tool for Longevity Data. Proceedings of the 48th Annual Meeting of the EAAP, Vienna, Austria, 25-28 August 1997, 116-117.

[53] Ducrocq, V., Quaas, R.L., Pollak, E.J. and Casella, G., (1988) Length of Productive Life of Dairy Cows. 1. Justification for a Weibull Model. Journal of Dairy Science, 71, 3061-3070. https://doi.org/10.3168/jds.S0022-0302(88)79906-3

[54] Sewalem, A., Kistemaker, G.J, Ducrocq, V. and Van Doormaal, B.J. (2005) Genetic Analysis of Herd Life in Canadian Dairy Cattle on a Lactation Basis Using a Weibull Proportional Hazards Model. Journal of Dairy Science, 88, 368-375. https://doi.org/10.3168/jds.S0022-0302(05)72696-5

[55] Ducrocq, V. (2005) An Improved Model for the French Genetic Evaluation of Dairy Bulls on Length of Productive Life of Their Daughters. Animal Science, 80, 249-256. https://doi.org/10.1079/ASC41720249

[56] de Mello, F., Kern, E.L. and Bretas, A. (2014) Longevity in Dairy Cattle. Journal of Advances in Dairy Research, 2, Article ID: 1000126. https://doi.org/10.4172/2329-888X.1000126

[57] Buenger, A., Ducrocq, V. and Swalve, H.H. (2001) Analysis of Survival in Dairy Cows with Supplementary Data on Type Scores and Housing Systems from a Region of Northwest Germany. Journal of Dairy Science, 84, 1531-1541. https://doi.org/10.3168/jds.S0022-0302(01)70187-7

[58] Vukasinovic, N. (1999) Application of Survival Analysis in Breeding for Longevity. Proceedings of the 4th International Workshop on Genetic Improvement on Functional Traits in Cattle, Jouy-en-Josas, Interbull Bulletin No. 21, Uppsala, 3-10.

[59] Larroque, H. and Ducrocq, V. (2001) Relationships between Type and Longevity in the Holstein Breed. Genetics Selection Evolution, 33, 39-59.

https://doi.org/10.1186/1297-9686-33-1-39

[60] Lavrinovič, J., Juozaitienė, V., Žymantienè, J., Juozaitis, A., Sauliūnas, G. and Brazauskas, A. (2009) Genetic Correlations between the Length of Productive Life and Exterior in Lithuanian Dairy Cattle. Veterinarija ir Zootechnika, 46, 43-47.

[61] Dadpasand, M., Miraei-Ashtiani, S.R., Moradi Shahrebabak, M. and Vaez Torshizi, R. (2008) Impact of Conformation Traits on Functional Longevity of Holstein Cattle of Iran Assessed by a Weibull Proportional Hazards Model. Livestock Science, 118, 204-211. https://doi.org/10.1016/j.livsci.2008.01.024

[62] Morek-Kopeć, M. and Zarnecki, A. (2012) Relationship between Conformation Traits and Longevity in Polish Holstein Friesian Cattle. Livestock Science, 149, 53-61. https://doi.org/10.1016/j.livsci.2012.06.022

[63] Zavadilova, L., Sitpkova, M., Nemcova, E., Bouska, J. and Matejickova, J. (2011) Analysis of the Phenotypic Relationships between Type Traits and Functional Survival in Czech Fleckvieh Cows. Czech Journal of Animal Science, 54, 521-531. https://doi.org/10.17221/29/2009-CJAS

[64] Malhado, C.H.M., Malhado, A.C.M., Carneiro, P.L.S., Ramos, A.A., Carrillo, J.A. 
and Pala, A. (2013) Inbreeding Depression on Production and Reproduction Traits of Buffaloes from Brazil. Animal Science Journal, 84, 289-295.

https://doi.org/10.1111/asj.12006

[65] Maiwashe, A., Nephawe, K.A., Van der Westhuizen, R.R., Mostert, B.E. and Theron, H.E. (2006) Rate of Inbreeding and Effective Population Size in Four Major South African Dairy Cattle Breeds. South African Journal of Animal Science, 36, 50-57. https://doi.org/10.4314/sajas.v36i1.3986

[66] Mirhabibi, S., Manafiazar, G.H., Qaravisi, S. and Mahmoodi, B. (2007) Inbreeding and Its Effect on Some Productive Traits in Buffaloes of South Iran. Italian Journal of Animal Science, 6, 372-374. https://doi.org/10.4081/ijas.2007.s2.372

[67] Mostert, B.E. (2011) Inbreeding Facts of the South African Jersey Breed. South African Jersey Journal, 60, 40-45. 